\title{
PEMAHAMAN MAHASISWA ATAS METODE PENELITIAN KUALITATIF: SEBUAH REFLEKSI ARTIKEL HASIL PENELITIAN
}

\author{
Widya Hanum Sari Pertiwi, Riza Weganofa
}

\author{
Email: hanoems@gmail.com \\ Program Studi Pendidikan Bahasa Inggris Universitas Kanjuruhan Malang \\ Alamat Korespondensi: JL. S. Supriadi 48 Universitas Kanjuruhan Malang
}

\begin{abstract}
This article aimed at describing students' difficulties in writing researchbased paper. It is expected that lecturers who teach research methodology course will get a lot of benefit from this study. The respondents of this research was 131 students who conducted a research which employed qualitative design and wrote their articles which showed the research results. The data gained showed that the university students' who became the respondents had difficulties in writing research-based article related toqualitative research design. The difficulties were: most of the students showed their difficulties in identifying the research instrument, data sources, and relevant sources that support their research. Next, they were also had obstacle in explaining or discussing the result of their research. It means that they did not understand that qualitative researchdesign employs snowballing technique and enabling the researcher to generate theory.
\end{abstract}

Keywords: research-based paper, students' difficulties, qualitative design

\section{PENDAHULUAN}

Dapat menulis tulisan akademik merupakan sebuah keharusan bagi mahasiswa di jenjang perguruan tinggi. Kemampuan ini melibatkan beberapa aspek yakni kemampuan dalam menulis esai dasar, meramu teori yang relevan, hingga pemahaman terhadap metode penelitian yang digunakan. Menulis sebagai salah satu keterampilan berbahasa memang bukan sebuah hal yang mudah. Ketika menulis mahasiswa cenderung kesulitan dalam mengekspresikan ide mereka. Keterbatasan kosakata dan rumus-rumus grammar (grammatical rules) seringkali menjadi alasan kesulitan dalam merangkai kata agar menjadi kalimat dan merangkai kalimat-kalimat agar menjadi sebuah paragraf yang padu. Hal ini seringkali muncul bersamaan dengan lemahnya motivasi menulis dan kurangnya rasa percaya diri mahasiswa. Ghaitzh (2002, h.1) menjelaskan bahwa menulis adalah proses kompleks yang mengharuskan penulis untuk menggali ide dan pemikiran serta menjadikannya nampak nyata. Ketika pemikiran atau ide dituangkan dalam tulisan, ide tersebut tentu dapat ditelaah, dipertimbangkan, ditambah, dan bahkan diubah.

Menurut Cahyono \& Widiati (2011, h.73) tulisan berupa artikel adalah produk tulisan yang fokus pada deskripsi atau kajian tentang ilmu pengetahuan yang terpapar di alam semesta, dimana pada teks tersebut muncul referensi tertentu. Sedangkan menurut Rusyanti $(2013$, h.1) artikel adalah karya tulis yang dirancang untuk dimuat dalam jurnal atau buku kumpulan artikel yang ditulis dengan tata cara ilmiah dan mengikuti pedoman atau konvensi ilmiah yang telah disepakati atau ditetapkan. Dari dua definisi tersebut dapat disimpulkan bahwa artikel adalah sebuah karya tulis yang memaparkan informasi kekinian serta memiliki ciri khas tertentu sesuai pedoman yang ditetapkan

Untuk memahami lebih dalam terkait dengan kemampuan tersebut, peneliti melakukan penelitian terhadap kesulitan mahasiswa ketika mengaplikasikan ilmu 
metode penelitian (khususnya desain kualitatif) yang telah mereka pelajari. Penelitian ini dalam jangka pendek bertujuan untuk memetakan letak kesulitan mahasiswa dalam menulis artikel hasil. Peneliti mengharapkan dari hasil penelitian ini dosen pengampu mata kuliah metode penelitian dapat mengambil manfaat untuk pengajaran di kelas tersebut yakni mendorong mereka agar mengambil langkah dan strategi belajar yang efektif agar mahasiswa lebih mudah dalam memahami dan mengaplikasikan bermacam desain penelitian, khususnya desain kualitatif. Sedangkan tujuan khusus dari penelitian ini adalah untuk mendapatkan gambaran yang jelas mengenai kesulitan mahasiswa selama proses menulis artikel hasil penelitian dari segi pemahaman mereka terhadapmetode penelitian kualitatif.

Tulisan produk mahasiswa yang akan dikaji dalam penelitian ini adalah artikel hasil penelitian kualitatif dalam mata kuliah Pragmatics. Artikel tersebut memiliki tiga bagian utama: pendahuluan, isi (kajian teori, temuan, dan refleksi/diskusi), serta kesimpulan. Sedangkan metode penelitian yang digunakan oleh responden adalah penelitian kualitatif. Penelitian kualitatif adalah proses pemecahan masalah yang bertujuan untuk memahami fenomena yang berhubungan dengan manusia, dengan latar belakang sosial maupun kultural. Penelitian ini dilakukan dengan tidak menganalisa angka dan melaporkan deskripsi hasil penelitian secara detail. Penelitian kualitatif mencari tahu "apa, bagaimana, kapan, dan dimana sebuah kejadian untuk mendapatkan sebuah arti, konsep, definisi, karakteristik, metafora, simbol, maupun deskripsi (Angrosino, 2007, h.1).

Menurut Latief (2014, h.76-84) penelitian ini memiliki beberapa ciri, yaitu: (1) generate theory. Penelitian ini memahami objek tanpa sebuah teori yang pasti akan sesuai dengan kondisi di lapangan. Oleh sebab itu, teori yang ada tidak akan mendikte apa yang seharusnya dilakukan peneliti untuk memahami objek penelitian, (2) rumusan masalah bersifat fleksibel. Dalam penelitian kualitatif rumusan masalah dapat berubah lebih fokus saat peneliti merasa bahwa apa yang digalinya terlalu luas, (3) data dalam penelitian ini adalah data verbal yang dikumpulkan dengan mengobservasi lingkungan / manusia ketika mereka berinteraksi dalam lingkungan alamiahnya, sehingga perilaku dan kata-kata yang muncul dapat diletakkan sesuai konteks, (4) seting penelitian natural/alami, (5) sumber data dalam penelitian kualitatif adalah informan yang memiliki legitimasi terhadap masalah yang sedang dikaji, (6) sumber data penelitian ini beragam, (7) teknik pengumpulan data dan instrumen yang digunakan bervariasi serta peneliti adalah instrumen utama, (8) proses dalam penelitian kualitatif adalah sebuah penelitian yang sirkuler dimana snowballingtechnique digunakan jika data yang didapatkan belum mencukupi, (9) penelitian kualititatif bertumpu pada proses bukan produk.

\section{METODE}

Pendekatan yang dilakukan dalam penelitian ini adalah penelitian kualitatif dengan peneliti sebagai instrumen utama penelitian. Adapun instrumen tambahan untuk mengumpulkan data adalah berupa kuesioner dan observasi terhadap artikel hasil penelitian responden. Sumber data penelitian ini adalah 131 mahasiswa prodi bahasa Inggris yang melakukan penelitian mini dalam mata kuliah Pragmatik.

Untuk mengumpulkan data, maka peneliti melakukan beberapa tahapan yaitu: (a) menentukan mahasiswa yang menjadi subyek penelitian, (b) melakukan observasi selama proses konsultasi artikel berlangsung, (c) mengumpulkan artikel hasil penelitian mahasiswa.

Mendistribusikan kuesioner kepada mahasiswa. Sedangkan dalam menganalisa data pertama peneliti akan melakukan reduksi terhadap data yang relevan dengan tujuan penelitian. Kemudian, peneliti menyajikan data tersebut dalam bentuk naratif untuk kemudian di verifikasi berdasarkan kajian teori yang telah ditetapkan dan menarik kesimpulan darinya.

\section{HASIL DAN PEMBAHASAN}

Kuesioner yang diberikan kepada mahasiswa terdiri dari dua bagian. Bagian pertama adalah bagian dengan jawaban yang sudah ditentukan untuk dipilih (yes atau no). Bagian kedua adalah bagian dengan jawaban isian bebas yang memudahkan mahasiswa untuk menjelaskan apa yang mereka 
kemukakan secara bebas. Secara umum, ada ketimpangan pada hasil kuesioner yang diisi responden. Secara umum mayoritas responden kami menyatakan paham terhadap desain penelitian mereka, namun mereka gagal dalam menyebutkan instrumen penelitian mereka. Tabel berikut menunjukkan hasil kuesioner dari bagian pertama.

Table 1. Hasil Isian Angket

\begin{tabular}{|c|c|c|c|c|c|c|}
\hline \multirow[t]{2}{*}{ Pertanyaan } & \multicolumn{2}{|c|}{ Yes } & \multicolumn{2}{|c|}{ No } & \multicolumn{2}{|c|}{$\begin{array}{c}\text { Tidak } \\
\text { menjawab }\end{array}$} \\
\hline & $\mathbf{F}$ & $\%$ & $\mathbf{F}$ & $\%$ & $\mathbf{F}$ & $\%$ \\
\hline $\begin{array}{l}\text { Saya baca } \\
\text { buku metode } \\
\text { penelitian } \\
\text { (kualitatif) } \\
\text { sebelum } \\
\text { melakukan } \\
\text { penelitian }\end{array}$ & 63 & $48 \%$ & 67 & $51 \%$ & 1 & $1 \%$ \\
\hline $\begin{array}{l}\text { Saya } \\
\text { memahami } \\
\text { desain } \\
\text { penelitian } \\
\text { saya }\end{array}$ & 113 & $86 \%$ & 13 & $10 \%$ & 5 & $4 \%$ \\
\hline $\begin{array}{l}\text { Saya } \\
\text { memahami } \\
\text { instrumen } \\
\text { penelitian } \\
\text { saya }\end{array}$ & 92 & $70 \%$ & 29 & $22 \%$ & 10 & $8 \%$ \\
\hline $\begin{array}{l}\text { Saya } \\
\text { membaca } \\
\text { buku } \\
\text { Pedoman } \\
\text { Penulisan } \\
\text { Karya Ilmiah } \\
\text { sebelum/ } \\
\text { pada saat } \\
\text { menulis } \\
\text { artikel }\end{array}$ & 49 & $37 \%$ & 80 & $61 \%$ & 2 & $2 \%$ \\
\hline $\begin{array}{l}\text { Mayoritas } \\
\text { rujukan saya } \\
\text { adalah } \\
\text { internet }\end{array}$ & 86 & $66 \%$ & 44 & $33 \%$ & 1 & $1 \%$ \\
\hline $\begin{array}{l}\text { Saya } \\
\text { membaca } \\
\text { buku teori } \\
\text { yang relevan } \\
\text { terhadap } \\
\text { penelitian } \\
\text { saya }\end{array}$ & 87 & $66 \%$ & 41 & $31 \%$ & 3 & $2 \%$ \\
\hline $\begin{array}{l}\text { Saya } \\
\text { membaca } \\
\text { artikel jurnal } \\
\text { yang terkait } \\
\text { dengan } \\
\text { penelitian } \\
\text { saya }\end{array}$ & 81 & $62 \%$ & 47 & $36 \%$ & 3 & $2 \%$ \\
\hline $\begin{array}{l}\text { Saya } \\
\text { membaca } \\
\text { skripsi yang } \\
\text { terkait } \\
\text { dengan hasil } \\
\text { penelitian } \\
\text { saya }\end{array}$ & 30 & $23 \%$ & 99 & $75 \%$ & 2 & $2 \%$ \\
\hline
\end{tabular}

Terlihat dari hasil tabel tersebut bahwa

$51 \%$ (67 orang) responden menyatakan bahwa mereka tidak membaca buku metode penelitian sebelum melakukan penelitian. Sedang $1 \%$ dari reponden (seorang mahasiswa) tidak menjawab pertanyaan ini. Berikutnya, kendati hanya separuh dari responden yang menyatakan tidak membaca buku metode penelitian, $86 \%$ diantaranya (113 orang) menyatakan bahwa mereka memahami desain penelitian mereka, yakni desain kualitatif. Terlebih, 70\% dari reponden kami (92 orang) menyatakan bahwa mereka paham instrumen yang digunakan dalam penelitian mereka dan 8\% diantaranya (10 orang) tidak dapat menentukan apakah mereka memahami instrumen penelitian mereka atau tidak.

Selanjutnya, poin keempat hingga kedelapan fokus untuk menggali "sumber yang terkait dengan penelitian" yang dibaca oleh mahasiswa. Dari 131 responden, 80 diantaranya (61\%) mengakui bahwa mereka tidak membaca buku pedoman penulisan karya ilmiah sebelum/pada saat menulis artikel. Namun, 37\% dari mereka (49 orang) mengklaim bahwa mereka telah membaca buku metode penelitian sebelum/pada saat mengerjakan artikel ilmiah mereka. Hal menarik lainnya adalah bahwa 66\% (86 orang) responden kami mengakui bahwa mereka menjadi internet sebagai rujukan utama. Terlebih, 30 responden (23\%) kami menyatakan bahwa mereka cenderung membaca skripsi yang terkait dengan penelitian mereka. Terkait poin keenam dan ketujuh, hanya 41 responden kami yang menyatakan bahwa mereka tidak membaca buku teori yang relevan dengan penelitian mereka dan 47 orang menyatakan bahwa mereka tidak membaca artikel atau jurnal yang terkait penelitian mereka.

Maka, kesimpulan umum dari bagian pertama kuesioner ini menunjukkan bahwa mahasiswa mampu menulis artikel penelitian sebab mereka secara mayoritas menunjukkan perilaku positif pada kegiatan yang menunjang penelitian hingga penulisan artikel hasil penelitian yang meliputi: memahami desain penelitian, membaca rujukan yang relevan, dan melakukan editing pada tulisan mereka.

Akan tetapi, bagian kedua dari kuesioner yang kami distribusikan menunjukkan beberapa hal yang berkebalikan dari hasil bagian pertama kuesioner. Poin 
yang paling menarik untuk disajikan pertama adalah pertanyaan mengenai intrumen yang digunakan. Dari hasil kuesioner yang ada, tidak ada satupun dari responden kami yang berhasil menyatakan bahwa instrumen utama penelitian kualitatif yang mereka lakukan adalah manusia (peneliti itu sendiri). Bahkan 45 responden kami tidak menjawab pertanyaan pada poin ini, 6 diantaranya menyebutkan interview sebagai instrumen, 8 responden menyebutkan observasi sebagai instrumen dan seorang responden menyatakan bahwa instrumennya adalah merekam. Berikutnya 71 dari keseluruhan responden kami gagal mendeskripsikan instrumen penelitian mereka. 71 orang mahasiswa ini menjawab bahwa responden mereka adalah data, laptop, alat tulis, bahkan ada yang menyebutkan teori yang mereka gunakan. Kesimpulan pada poin ini adalah bahwa mayoritas responden (116 mahasiswa atau $89 \%$ ) tidak paham intrumen penelitian kualitatif.

Selanjutnya, kesulitan mahasiswa nampak juga dari hasil kuesioner mengenai deskripsi buku atau jurnal yang menjadi referensi tulisan mereka. Sebanyak 71 orang responden menyebutkan buku atau beberapa buku dan jurnal yang menjadi rujukan artikel, namun mereka tidak bisa menyebutkan judul buku dan nama pengarang dengan pasti. Terlebih, merekapun tidak bisa mendeskripsikan secara ringkas apa isi rujukan tersebut yang terkaiit dengan penelitian mereka. Beberapa diantara mereka menyebutkan lupa nama penulis jurnal atau buku yang mereka bawa, menuliskan nama penulis saja tanpa judul jurnal/buku, menuliskan deskripsi ringkas saja tanpa menulis judul rujukan yang dibaca beserta pengarangnya, bahkan ada yang menuliskan buku, e-book, PDF dan internet sebagai rujukan. Kemudian, 42 responden kami bahwa tidak menjawab pertanyaan seputar rujukan ini. Maka dari sini dapat disimpulkan bahwa sebagian besar responden kami (113 orang atau $86 \%$ ) tidak benar-benar membaca atau memahami rujukan mereka dalam penelitian yang telah mereka lakukan. Dan hanya terdapat 18 orang mahasiswa (14\%) saja yang mampu menyebutkan penulis jurnal/ buku yang mereka baca berikut mendeskripsikan apa isi rujukan tersebut yang terkait dengan penelitian mereka.
Kemudian, masih pada ruang lingkup yang sama yakni seputar metode penelitian, 30 orang responden kami tidak menyebutkan sumber data penelitian mereka dengan benar. Adapun perinciannya adalah: 2 orang mahasiswa tidak menuliskan sumber data mereka; 11 orang mahasiswa menyebutkan internet, jurnal, judul buku bahkan teori sebagai sumber data mereka; 15 orang menyebutkan referensi bersama dengan sumber data berupa orang (kelompok orang tertentu) sebagai sumber data, dan 3 responden menyebutkan sumber data yang terlalu umum yakni kontrakan serta orang jawa dan madura sebagai sumber data. Maka dapat ditarik sebuah kesimpulan bahwa masih ada sebagian kecil (23\%) responden kami yang belum memahami siapa atau apa sumber data penelitian mereka dan $77 \%$ diantara keseluruhan responden kami telah mampu menunjukkan siapa sumber data penelitian mereka.

Kemudian, pertanyaan berikutnya dalam kuesioner ini terkait dengan cara/ langkah dalam mengumpulkan data penelitian. Hasil kuesioner menunjukkan hanya 18 responden (14\%) yang berhasil merusmuskan langkah pengumpulan data secara berurutan mulai dari wawancara atau observasi, menuliskan data mentah, menyeleksi data yang relevan, dan menuliskan data akhir. Sedangkan sisa dari responden (86\%) terbagi menjadi dua kelompok. Kelompok pertama adalah kelompok responden yang tidak berhasil menuliskan langkah mengumpulkan data dengan lengkap (sebanyak 94 mahasiswa atau 72\%), misalnya: hanya menyebutkan wawancara atau observasi, menyebutkan dua atau tiga langkah seperti mengamati dan menuliskan data, menelpon dan menulis sms lalu mengolahnya, memperhatikan dan mencatat percakapan, dan sebagainya. Sedangkan kelompok kedua adalah sebagian kecil mahasiswa (19 orang atau $14 \%$ ) yang menyatakan membaca teori, membaca jurnal, membaca skripsi dan sejenisnya sebagai langkah untuk mengumpulkan data. Hal ini menunjang kseimpulan bahwa mahasiswa mengalami kesulitan dalam menjelaskan cara atau langkah dalam mengumpulkan data sebab mayoritas dari mereka tidak dapat mendeskripsikan langkah pengumpulann data dengan rinci dan tepat. 
Berikutnya, hasil observasi pada artikel penelitian mahasiswa sebagai sumber data dapat dikategorikan kedalam beberapa bagian, yaitu: minimnya diskusi atau refleksi hasil temuan, serta lemahnya pemahaman dalam hal merujuk pendapat ahli.

Artikel responden kami juga menunjukkan minimnya pembahasan atau refleksi hasil penelitian mereka. Bagian pembahasan seharusnya berisi diskusi yang padat dan berbobot antara hasil dengan kajian teori atau juga berisi refleksi yang bisa ditarik oleh peneliti terhadap hasil temuan. Namun demikian, mayoritas responden kami mengalami kesulitan pada bagian ini. Tulisan LPA berikut adalah salah satu contohnya. REFLECTION

The data that I have got is show that the hearer understands what the speaker means. I think speech act is always used in conversation everyday. Almost al people in my boarding house using speech act. But, they don't know what speech act itself.

Terlihat pada tulisan di atas bahwa salah satu responden kami tidak telah gagal dalam menggali bahan untuk didiskusikan pada bagian ini. LPA tidak menunjukkan adanya korelasi antara temuannya dengan kajian pustaka yang tertulis sebelumnya dan juga tidak menyebutkan poin yang bisa dia tarik manfaat dari hasil temuannya.

Kemudian, artikel yang ditulis oleh LF dan NYW juga menunjukkan hal serupa sebagai berikut.

DISCUSSION

Data indicate that the listener should be able to understand the intent and purpose of the speaker, as this will clarify the intent and purpose of the speaker so as to avoid ambiguity and clarify the nature of the hidden mean on the conversation. The assumption that of participants in a conversation normally attempt to be informative, truthful, relevant, and clear. (Paul Grice).

Within this principle, be suggested 4 maxims (Grice). Maxim of quality (do not say what you believe to false), maxim of quantity (give the most information), maxim of manner, and maxim of relevance (be relevan).

Terlihat pada salinan data tersebut bahwa responden kami menulis pendapat ahli pada bagian diskusi yang sangat minim tersebut. Apa yang mereka tuliskan tidak lebih dari sekedar penjiplakan tanpa mengetahui apa yang harusnya tertulis pada bagian pembahasan.

Berikutnya, hasil observasi pada artikel mahasiwa juga menunjukkan bahwa mayoritas dari mereka belum mengetahui apa rujukan yang relevan, bagaimana menulis rujukan, dan bagaimana menulis sumber ini dalam bagian daftar pustaka. Banyak diantara responden kami yang menulis nama lengkap penulis dengan tanpa disertai tahun penulisan. Kemudian, banyak juga diantara mereka yang merujuk pada sumber tulisan yang tidak relevan. Misalkan pada daftar pustaka tertulis www.wikipedia.com. Terlebih banyak diantara responden penelitian ini yang tidak menuliskan daftar pustaka dengan benar seperti: urutan daftar pustaka yang tidak sesuai abjad dan menulis daftar pustaka yang tidak sesuai dengan panduan penulisannya.

Melihat hasil paparan data diatas, maka nampak jelas dari hasil kuesioner maupun data berupa artikel bahwa pemahaman mayoritas mahasiswa tentang metode penelitian kualitatif masih sangat rendah. Dalam isian kuesioner tertutup responden kami menyatakan paham desain penelitian yang mereka ambil, paham instrumen mereka, dan membaca buku teori penelitian kualitatif, namun keseluruhan responden gagal dalam menyebutkan peneliti sebagai instrumen utama dalam penelitian. Hal ini tentu bertolak belakang dengan ciri metode penelitian kualitatif yang mana menurut Latief (2014, h.81) teknik pengumpulan data dan instrumen yang digunakan bervariasi serta peneliti adalah instrumen utama. Berikutnya, ketidakpahaman mahasiswa terhadap metode penelitian kualitatif juga nampak pada kegagalan mereka dalam menyebutkan sumber data penelitian mereka. Kemudian, mereka juga gagal dalam memahami bahwa penelitian ini juga bersifat generate theory dan menggunakan snowballingtechnique. Masih menurut Latief (2014, h.83) bahwa penelitian kualitatif menjadikan peneliti mampu memunculkan teori baru hasil pemahaman mereka akan seting alamiah data penelitian mereka dan temuan ini dapat bersifat semakin mendalam dan mendetail dengan adanya snowballingtechnique tersebut. Fakta dari hasil penelitian ini bahwa mahasiswa secara mayoritas gagal dalam menggali bahan yang seharusnya mereka diskusikan dan refleksikan. 


\section{SIMPULAN}

Berdasarkan paparan data temuan dan pembahasaan di atas, maka dapat disimpulkan bahwa, dalam konteks penelitian ini, mahasiswa mengalamai kesulitan dalam memahami metode penelitian kualitatif dalam beberapa aspek. Aspek pertama adalah dalam memahami seting alamiah desain kualitatif dengan sumber data berupa orang/informan atau teks. Aspek kedua adalah dalam hal memahami manusia/peneliti sebagai instrumen utama penelitian. Sedangkan aspek ketiga, mahasiswa juga kesulitan dalam hal memahami ciri desain kualitatif yang bersifat generating theory dengan menggunakan snowballing technique. Maka, perlu kiranya bagi dosen matakuliah metode penelitian (khususnya di Universitas Kanjuruhan) untuk mengambil langkah efektif pada pengajaran mata kuliah ini agar mahasiswa memahami metode penelitian kualitatif. Sehingga pada gilirannya, artikel ilmiah yang dihasilkan mahasiswa menunjukkan kualitas yang maksimal.

\section{DAFTAR PUSTAKA}

Angrosino, M.V. (2007). Naturalistic Observation. CA: Left Coast Press Inc.

Cahyono, B.Y \& Utami, W. (2011). The Teaching of English as a Foreign language in Indonesia. Malang: UM Press.

Ghaitzh, G. (2002). Writing The Nature of Writing Process, Approaches, and Models and Process Writing Activities, (online), (http://ghaith.tsx.org), diakses pada 12 February 2008.

Latief, M.A. (2014). Research Methods On Language Learning: An Introduction. Malang: UM Press.

Rusyanti, H. (2013). Definisi Artikel: Pengertian dan Ciri-ciri Artikel, (Online), (http://www.kajianteori.com/2013/03/definisi-artikel-pengertian-dan-ciri-ciri-artikel.html, diakses pada 18 November 2014) 